\title{
Greenhouse gas emissions from livestock and mitigation options in Nigeria
}

*Adeyemi, M. A. and Akinfala, E. O.

*Department of Animal Production and Health, Olusegun Agagu University of Science

and Technology, Okitipupa

Department of Animal Sciences, Obafemi Awolowo University, Ile-Ife

*Corresponding author: ma.adeyemi@oaustech.edu.ng

\section{Abstract}

Greenhouse gases are becoming devastating on agriculture and environment because of its effect on climate and global warming. The aim of this review is to provide update on livestock greenhouse gases emission and rekindle available mitigation strategies. Recently, global warming and climate change have become one of the most discussed issues globally because of their negative effect on ecosystem worldwide. The livestock sub-sector as a major source of greenhouse gas emission, has been identified to contribute substantially to the recent rise in global warming and climate change. Livestock, most importantly ruminants plays a major role in the emission of methane, one of the potent greenhouse gases. This methane is usually released through enteric fermentation in animals and manure management system, though the latter account for smaller quantity. Estimate of methane emission inventory from livestock in Nigeria showed that $96.15 \%$ of methane produced by livestock was by ruminants with cattle alone accounting for $74.06 \%$. With this background, strategies to date for reducing methane emissions should centre on ruminant. Efforts to reduce methane emissions from enteric fermentation generally focus on options for improving production efficiency. This has been demonstrated with intensive animal production systems. However, in Nigeria, this system has been successful only for non-ruminants while the extensive and semi extensive systems are being practiced for ruminants. In view of this, options for reducing emissions must be selected to be consistent with country-specific circumstances. Those circumstances should include animal management practices (including cultural traditions), nutrition and economic development priorities.

Keywords: greenhouse gases, livestock, emission, enteric fermentation, mitigation

\section{Émissions de gaz à effet de serre provenant des options de bétail et d'atténuation au Nigéria}

\section{Résumé}

Les gaz à effet de serre deviennent dévastateurs de l'agriculture et de l'environnement en raison de son effet sur le climat et le réchauffement de la planète. L'objectif de cet examen est de fournir une mise à jour sur les stratégies d'atténuation disponibles des gaz à effet de serre de bétail. Récemment, le réchauffement climatique et le changement climatique sont devenus l'une des questions les plus discutées à l'échelle mondiale en raison de leur effet négatif sur l'écosystème mondial. Le sous-secteur de l'élevage en tant que source majeure d'émissions de gaz à effet de serre, a été identifié pour contribuer de manière substantielle à la hausse récente du réchauffement de la planète et du changement climatique. Le bétail, plus important encore, les ruminants jouent un rôle majeur dans l'émission de méthane, l'un des gaz à effet de serre puissants. Ce méthane est généralement libéré par la fermentation entérique chez les animaux et le système de gestion de fumier, bien que ces derniers représentent une plus petite quantité. L'estimation des stocks d'émissions de méthane provenant du bétail au Nigéria a montré que 96,15\% de méthane produites par le bétail 


\section{Greenhouse gas emissions from livestock and mitigation options in Nigeria}

étaient par des ruminants avec des bovins à eux-mêmes représentant 74,06\%. Avec ce contexte, des stratégies à ce jour pour réduire les émissions de méthane doivent être centrées sur le ruminant. Les efforts visant à réduire les émissions de méthane de la fermentation entérique se concentrent généralement sur les options d'amélioration de l'efficacité de la production. Cela a été démontré avec des systèmes de production d'animaux intensifs. Cependant, au Nigéria, ce système n'a abouti que pour les non-ruminants tandis que les systèmes étendus et semi-étendus sont pratiqués pour les ruminants. Compte tenu de cela, les options de réduction des émissions doivent être sélectionnées pour être cohérentes avec des circonstances spécifiques à chaque pays. Ces circonstances devraient inclure des pratiques de gestion des animaux (y compris des traditions culturelles), des priorités de nutrition et de développement économique.

Mots-clés: gaz à effet de serre, bétail, émission, fermentation entérique, atténuation

\section{Introduction}

Livestock production represents a universal practice across culture and contributes significantly to agriculture greenhouse gases (GHGs) emissions (Smith et al., 2014). The primary GHGs particularly generated from livestock production are methane $\left(\mathrm{CH}_{4}\right)$ and nitrous oxide $\left(\mathrm{N}_{2} \mathrm{O}\right)$ (IPCC, 2013). Methane emission especially occurs during enteric fermentation in ruminant particularly cattle while $\mathrm{N}_{2} \mathrm{O}$ is mostly emitted from manure management in swine. For instance, enteric fermentation represents $36 \%$ of total agriculture emissions while livestock manure management accounted for about $60 \%$ of global $\mathrm{N}_{2} \mathrm{O}$ emission (Syakila and Kroeze, 2011; Smith et al., 2014). Apparently, livestock production accounted for a greater environmental burden, accounting for about half of agricultural GHG emissions (Jan Kramer et al., 1999; Garett, 2009) and $18 \%$ of global GHG emission. Global GHGs emission pre-Industrial era was estimated at 21,446 $\mathrm{MtCO}_{2} \mathrm{e}$ while emission estimates have more than double between 1960 and 2017 (Tubiello et al., 2014; FAOSTAT, 2020). In the case of Nigeria, emission estimates were $123.11 \mathrm{MtCO}_{2} \mathrm{e}$ in 1990 and 492.44 $\mathrm{Mt} \mathrm{CO}_{2}$ e in 2014 (CAIT, 2017). By implication, these values indicated $25 \%$ rise in national emissions while the actual national contribution to global GHG emission was $1.01 \%$, making Nigeria to be ranked ninth among the top 25 emitting nations of the world (CAIT, 2018; USAID, 2019). The recent upsurge in GHG emissions has raised concerns among several researchers across the world. One of the major drivers of this upsurge is the rise in global demand for animal protein particularly meat and milk, to meet the increasing human population (FAO, 2011; UN, 2017). This has consequently increased the number of animals, acreage of land cleared for feed grains, pasture and grassland, severe manure management challenges and an almost 'dangerous climate change' scenario. Nevertheless, Nigeria livestock population continue to grow by $67.27 \%$ for cattle, $42.14 \%$ for goats, $47.13 \%$ for sheep, $43.74 \%$ for swine and $68.11 \%$ for poultry in between 1991 and 2018 (FAOSTAT, 2021). Cattle production dominated the North and heavily scattered across the South and West with over $80 \%$ cattle herded by nomad pastoralists and grazing them on available green fodder while the remaining proportion is housed on commercial basis either for milk production or as research animals in several research institutions (Okediji, 1973; Blench, 1999; LawalAdebowale, 2012). Some of the sheep are herded along with the cattle while the goats are practically on extensive production system. The swine industry in Nigeria spreads across the South, extending towards 


\section{Adeyemi and Akinfala}

the West and parts of the North Central States including Kogi, Eastern Benue State, North of Katsina Ala and a region between the Jos Plateau and Southern Kaduna, where religion allows, and reared under intensive production system. However, for the poultry industry, majority of the birds are raised by rural households while about 25 to 30 percent are confined either for meat or egg production (Sonaiya et al., 1999). In effect, these livestock species occupy space, feed and excrete feaces. The many interactions with the environment generate GHGs through enteric fermentation occurring during digestion in ruminants although this also happens in swine but to a lesser extent during manure management. The overall effect of these GHGs emission is a changing climate presented as rise in global mean temperature, ocean levels, unpredictable changes in rainfall pattern, increased pest and disease infestation, soil erosion, drought, heat waves, desert encroachment, loss of crops and animal biodiversity (Bellarby et al., 2008; Gerber et al., 2013). The environmental challenges of climate change imposed by GHGs emissions from livestock are enormous. Efforts to meet local expectations and international environmental obligations as contained in the Kyoto Protocol for mitigation have received several attentions by the Conference of Parties (IPCC, 2006; Smith et al., 2007; Vibart et al., 2021). To this end, Nigeria in her Intended Nationally Determined Contribution (INDC) to reduce GHGs emission by $20 \%$ of 1990 level in 2030, highlighted reduction in gas flaring and bush burning as well as improving energy use efficiency through rural electrification and connection to national grid (FRN, 2014; USAID, 2019). However, lesser emphasis is given to livestock GHG emission despite agriculture sector representing the second largest emitter of potent GHGs. Besides, several research have evaluated livestock greenhouse gases emissions. This review sought to provide update on livestock GHG emission and rekindle available mitigation strategies.

Carbohydrate degradation and greenhouse gas production in livestock

Ruminants have evolved to fill an important ecological niche. They have specially adapted digestive tracts that allow them to survive on coarse herbage unlike the monogastrics which cannot utilise to any appreciable extent much of the plant materials produced in the world because a large part of its carbohydrate consists of simple sugars joined together by beta links. The enzymes produced in the gut of simple stomach animals cannot attack the beta bond thus, the glucose contained in these compounds is unavailable to animals. There are micro-organisms (bacteria, protozoa and fungi) which can breakdown cellulose and are responsible for the 'rotting down' of plant litter which falls to the ground (Falkowski et al.,2000). Ruminant animals have evolved to harness the ability of these micro-organisms in a symbiotic relationship. Ruminant animals have had to make anatomical adaptations and to reduce their dependency upon glucose. The microorganisms too have changed; many have become separate species which are only under the conditions which exist in the rumen. In swine, the relatively large caecum compared to other non-ruminants is the seat of microbial activities. Food eaten by ruminants is first chewed so as to reduce the physical size of the food particles and to mix it with the copious supply of saliva. After being swallowed, it passes down the esophagus to join the rest of the mass of digestion in the rumen. The amount of material in the reticulo-rumen is rather variable and depends on the type of diet the animal (Boudon et al., 2009; Patton et al., 2012; Williams et al., 2014; Perez-Barberia et al., 2017). For instance, when fed on very fibrous diet, the rumen content may account for nearly $20 \%$ of the body weight of cattle, 


\section{Greenhouse gas emissions from livestock and mitigation options in Nigeria}

but this value may drop to as low as $12 \%$ for animals receiving a diet with a high proportion of grain. The greater proportion of the material that enters the rumen will be carbohydrate of some sort. Most is probably beta-linked materials such as cellulose, although on some diets with a high concentration of grain, there may be significant amounts of alphapolysaccharides such as starch (Chesworth, 1992). When starch makes up a large proportion of the diet, some of it may escape the actions of the rumen microbes and pass unchanged to abomasum for digestion (Harmon and McLeod, 2001; Harmon et al., 2003; Richards et al., 2003). Digestion in ruminants is aided by the activity of bacteria, protozoa, and fungi present in the rumen of the animal, to ferment and break down the plant biomass eaten by the animal as part of a natural process called enteric fermentation. In the rumen, plant biomass is converted into volatile fatty acids (acetic, propionic and butyric), which pass the rumen wall and go to the liver through the circulatory system (Perez-Barberia, 2020).

2 pyruvate $+2 \mathrm{H}_{2} \mathrm{O} \longrightarrow 2$ Acetic acid + $\mathrm{CO}_{2}+2 \mathrm{H}_{2} \mathrm{O}+$ Energy

2 pyruvate $+4[\mathrm{H}] \longrightarrow 2$ propionic acid + $2 \mathrm{H}_{2} \mathrm{O}+$ Energy

2 pyruvate $+4[\mathrm{H}] \longrightarrow$ Butyric acid + $2 \mathrm{H}_{2} \mathrm{O}+$ Energy

However, in non-ruminants such as pigs, actual digestion of carbohydrate occurs in the small intestine by endogenous enzymes while the fibre fractions of the diet are fermented principally in the lower gut producing short chain fatty acids (SCFAs) namely acetic, propionic and butyric), gases $\left(\mathrm{CO}_{2}, \mathrm{H}_{2}\right.$, and $\left.\mathrm{CH}_{4}\right)$, urea and heat (Jorgensen et al., 2011). Metabolic $\mathrm{H}_{2}$ is also produced by gut microorganisms. The SCFAs are used to fulfil parts of the energy needs for maintenance (Jorgensen et al., 1997) while $\mathrm{CO}_{2}, \mathrm{CH}_{4}$ and $\mathrm{H}_{2}$ present in the rumen represent energy loss from the animal and are removed by eructation.

Mechanism of greenhouse gas production and emission in livestock

Methane is produced essentially in the rumen of ruminant animals under anaerobic condition. The methanogenic archaea utilizes the carbon dioxide $\left(\mathrm{CO}_{2}\right)$ and hydrogen $\left(\mathrm{H}_{2}\right)$ gas produced during microbial metabolism to produce $\mathrm{CH}_{4}$ while its emission from the reticulo-rumen represents an evolutionary adaptation that enables the rumen ecosystem dispose $\mathrm{H}_{2}$ which may alter carbohydrate fermentation and fibre degradation (McAllister and Newbold, 2008). Many of the $\mathrm{H}_{2}$ used up in this reaction are by product produced during the synthesis of the various volatile fatty acids

$2 \mathrm{CO}_{2}+8 \mathrm{H}_{2} \longrightarrow 2 \mathrm{CH}_{4}+4 \mathrm{H}_{2} \mathrm{O}+$ Energy $_{(55.22 \mathrm{MJ} / \mathrm{Kg})}$

Production of $\mathrm{CH}_{4}$ connotes substantial loss of dietary energy from the animal. On the average, $8 \%$ of the gross energy consumed in the diet is converted to $\mathrm{CH}_{4}$ and released during eructation (Brouwer, 1965). The process that produces and releases $\mathrm{CH}_{4}$ from the animal is very key; as inability to get rid of all $\mathrm{CH}_{4}$ from the rumen causes it to swell, and the animal suffers from the condition of bloat. If the condition persists unrelieved, the animal dies.

2 pyruvate $+8[\mathrm{H}] \longrightarrow \mathrm{Ch}_{4}+2 \mathrm{H}_{2} \mathrm{O}$

Production of $\mathrm{CH}_{4}$ gas in the rumen therefore, depends essentially on availability of excess $\mathrm{H}_{2}$ gas and this reaction represents a major path for the elimination of $\mathrm{H}_{2}$ from the rumen. The emission rate of enteric methane varies according to feed intake and digestibility. Poultry do not undergo enteric fermentation to any extent however, $\mathrm{CH}_{4}$ and $\mathrm{N}_{2} \mathrm{O}$ emissions are only generated during manure management. 
Importantly too, $\mathrm{CH}_{4}$ and $\mathrm{N}_{2} \mathrm{O}$ are both emitted from manure, and the quantity emitted is linked to environmental conditions, type of management and composition of the manure. Organic matter and nitrogen content of excreta are the main characteristics influencing emission of methane and nitrous oxide, respectively. Under anaerobic conditions, the organic matter is partially decomposed by bacteria producing methane and carbon dioxide. Storage or treatment of manure in an enclosed tank encourages anaerobic environment which increases methane production while emissions may further be improved by long storage periods under warm and wet conditions (EPA, 2010).

Production of $\mathrm{N}_{2} \mathrm{O}$ is through both nitrification and denitrification processes of the organic (such as protein) and inorganic (such as ammonium and ammonia) form of nitrogen contained in manure. Nitrification occurs aerobically and converts ammonium and ammonia to nitrites and then nitrates, while denitrification occur anaerobically, converting nitrates to nitrous oxide and nitrogen gas (Saggar, 2010). The balance between ammonium and ammonia is highly affected by $\mathrm{pH}$, with ammonia increasing as $\mathrm{pH}$ increases.

Livestock population, estimation of greenhouse gas emission and trend

The Nigeria livestock population has continued to increase from the 60's to date. Based on 1991 livestock census, there were $13,900,000$ heads of cattle, 34,500,000 heads of goats, 22,100,000 heads of sheep, $3,500,000$ heads of pigs and 114,300,000 poultry birds. Over the last two decades, the Nigeria livestock population has increased substantially to over 325 million species (FAOSTAT, 2021). This implies that more resources are needed to sustain the growth of the livestock industry under stringent environmental challenges including greenhouse gases emissions.

Estimation of GHGs emissions have become a global trend due to the increasing consequences particularly on the environment and food production and security. Up to date, Nigeria does not have reliable country specific emission data on livestock species but relies on FAO default values for estimation (FRN, 2018). Based on IPCC (1996) methods, emission can be estimated by multiplying the individual animal population with the default emission factor of the respective animal type for the specific activity. The activity data is the intensity or quantity of activity that led to emissions of GHGs while emission factor represents the rate at which a particular GHG is emitted. The Tier 1 emission equation as provided by IPCC (1996) is:

Emission $(G g)=L P . E f$

Ef $=$ (GE offeed. $Y m$ '365days) $/ 55.65$

$\mathrm{LP}=$ Livestock population

$\mathrm{EF}=$ Emission Factor

$\mathrm{Y}_{\mathrm{m}}=$ Methane conversion rate

$\mathrm{GE}=$ Gross energy of feed

$55.65=$ Energy content of methane $(\mathrm{MJ} / \mathrm{Kg}$ $\mathrm{CH}_{4}$ )

$\mathrm{Gg}=$ Giga gram (the unit of measurement)

The estimated GHG emission from each species of livestock is shown in Table 1. By livestock species, cattle contributed the greater proportion $(74.06 \%)$ followed by goat $(13.25 \%)$, sheep $(8.84 \%)$, pigs $(2.51$ $\%)$ and lastly poultry $(1.34 \%)$. Ruminants contributed with $96.15 \%$ and this is because the bulk of $\mathrm{CH}_{4}$ emissions occur during enteric fermentation. The trend in GHGs emissions in between the preIndustrial period and 2018 is shown in Figure 1. In 1961, less than $250 \mathrm{Gg}$ of $\mathrm{CH}_{4}$ emissions were recorded and continue to increase by almost the same magnitude. In between 2010 and 2012, there was an upsurge of over $100 \mathrm{Gg} \mathrm{CH}_{4}$ emission compared to the previous years. The surge may imply that, livestock production either increased or production efficiency reduced for those periods. Similar trend was 
observed for $\mathrm{CH}_{4}$ emission from manure management, although the magnitude of emission was very low. However, for $\mathrm{N}_{2} \mathrm{O}$ emission from manure management, the emission intensity seems to be constant despite the growth in livestock population. Overall, there was steady increase in both the magnitude and intensity of emission and this may be due to increase in livestock number arising from the need to meet the demand for meat, milk and egg for the rapidly increasing human population. This rising trend especially in $\mathrm{CH}_{4}$ emission is worrisome as it has unleashed several changes in the climatic condition, threatening human survival and food production.

Table 1: Estimated greenhouse gas emission from livestock

\begin{tabular}{|c|c|c|c|c|c|}
\hline \multirow[b]{2}{*}{ Species } & \multirow[b]{2}{*}{$\begin{array}{l}\text { Livestock population } \\
\text { (million) }\end{array}$} & \multicolumn{4}{|c|}{ Emission by Livestock Species } \\
\hline & & $\begin{array}{l}\mathrm{CH}_{4} \text { emission from } \\
\text { Enteric fermentation } \\
\text { (emission/head/year) }\end{array}$ & $\begin{array}{l}\mathrm{N}_{2} \mathrm{O} \text { emission from } \\
\text { Manure production } \\
\text { (Emission/head/year) }\end{array}$ & $\begin{array}{l}\text { Total GHG emission } \\
\text { (Gg) }\end{array}$ & $\%$ \\
\hline Cattle & $20,664,069$ & 950.547 & 8.120 & 958.667 & 74.06 \\
\hline Goats & $81,879,445$ & 163.758 & 7.696 & 171.454 & 13.25 \\
\hline Sheep & $46,893,030$ & 107.853 & 6.612 & 114.465 & 8.84 \\
\hline Swine & $8,001,217$ & 8.001 & 24.540 & 32.540 & 2.51 \\
\hline Poultry & $167,812,000$ & - & 17.35 & 17.35 & 1.34 \\
\hline Total & & $1,230.159$ & 64.318 & $1,294.476$ & \\
\hline
\end{tabular}

Emission factors are obtained from FAOSTAT (2021)

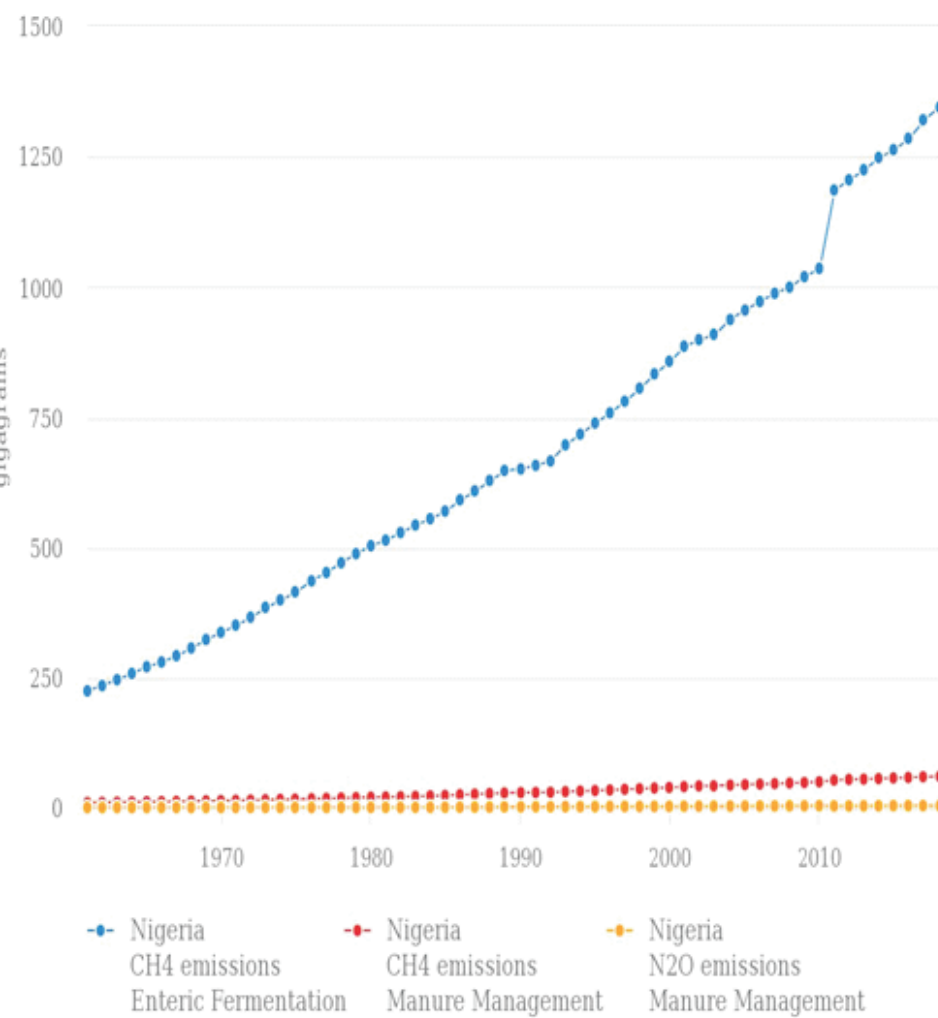

Figure 1: Trend in greenhouse gases emission between 1961 and 2018 Source: FAOSTAT (2021) 
The data in Table 1 showed that, the bulk of the methane produced by livestock in Nigeria is by cattle, sheep and goats (96.15 $\%)$. The result also shows that cattle alone accounted for the most of the methane $(74.06 \%)$ produced by livestock in Nigeria in the year 2018. This may probably be due to the fact that cattle are the most popular meat producing animal in Nigeria. Most homes especially in the urban and semi urban areas in Nigeria rely heavily on meat from cattle as the source of their animal protein. The popularity and acceptance of meat from cattle by majority of the populace in Nigeria may have accounted for its increased production at the expense of sheep and goats.

\section{Effects of greenhouse gas emission on livestock production and productivity}

The rise in livestock GHG emission has unsurprisingly contributed to the rise in global mean temperature and warming and significantly contributed to climate change and variability as well as impacted livestock production and productivity across regions of the world through heat stress. All livestock species have a range of ambient environmental temperature called thermo neutral zone above or below which creates a condition of stress for the animal. Variation in environmental temperature has been observed to reduce milk yield, length of lactation and infertility in animal (Dhakal et al., 2013).

\section{Impact on animal production}

Animals through their response mechanisms for survival can adapt to hot climate, however production and reproductive performance may be affected. Basically, animals will reproduce only when managed under appropriate environmental condition. Heat stress especially during the hot summer months has been observed to cause infertility in most farm animals (Chauhan and Ghosh, 2014). This is because as temperature rises, some functions of the reproductive hormones are inhibited. For instance, a rise in temperature above $2{ }^{\circ} \mathrm{C}$ could cause a temperature rise of $0.5^{\circ} \mathrm{C}$ in the uterine wall, resulting in $12.8 \%$ reduction in conception rate (Gwazdauskas et al., 2017). Heat stress produced reduced estrus in farm animals especially cattle and increases the incidence of anestrus and silent ovulation (Singh et al., 2011). Reproductive performance (sperm ejaculation volume, sperm concentration, total sperm number and percentage of normal sperm cells) of male animals decreased in hot season. This is particularly true with Bos indicus bulls in Africa.

\section{Impact on livestock health}

Global warming brought about by rising GHG emissions influences the ecological balance of the environment producing a shift in the feature of the region. This effect increases the transmission efficiency and spectrum of both the pathogen and host (Brooks and Hobergs, 2007). For instance, a change in rainfall and temperature regimes may affect the abundance and distribution of disease causing microbes (Thornton et al., 2009). Hot humid condition was reported to worsen infestation of cattle ticks such as Boophilus microplus, Haemaphysalis bispinosa, and Hyalomma anatolicum (Basu and Bandhyopadhyay, 2004; Kumar et al., 2004).

\section{Impact on feed}

The changing climatic condition can affect livestock production through alteration in quantity and quality of available feed. Changes in species composition of grassland, feed digestibility and nutrient quality of fodder are emerging occurrences of climate change (Thornton et al., 2009; Dikshit and Birthal, 2010). Also, changes in rainfall pattern can initiate intense feed scarcity with remarkable effects on livestock production.

Impact on milk production

Reduction in milk yield is one of the 


\section{Greenhouse gas emissions from livestock and mitigation options in Nigeria}

indicators of stress in lactating animals. Milk yield in cattle is adversely affected by increased number and frequency of stressful days (Upadhyay et al., 2007). Decline in milk yield by $0.2 \mathrm{Kg}$ per unit rise in Temperature Humidity Index (THI) when it exceeds 72 has been reported by Ravagnolo and Misztal (2000). Similar studies by Berman (2005) and Nardone et al. (2010) reported decrease milk production when high milk producing cows were managed under hot climatic zones with intensified metabolic heat production. In the case of small ruminants, high air temperature negatively affects milk yield and milk nutrient content (Sevi et al., 2001). Mitigation options for methane emission from livestock

The intricacy in defining absolute mitigation options for livestock greenhouse gas emissions may be due to differences in livestock species, production systems and climatic variations. This limits the capacity for a strategy to fully encompass all emission reduction potentials; hence combination of several selected options would produce a better outcome (Llonch et al., 2017). Some of the GHG emission strategies are summarized into three broad headings as follow;

\section{Nutrition}

Nutritional techniques exist for the improvement of rumen efficiency. This includes diet manipulation, use of direct inhibitors, feed additives, propionate enhancers, methane oxidisers, probiotics, defaunation and hormones (Zeoula et al., 2018). Diet composition has significant effect on rumen microbial ecosystem and so any manipulation in the diet by means of forage, concentrate and their components will results in change in the microbial community and may decrease or inhibit activity of methanogenic bacteria. Dietary manipulation can be achieved by increasing the quantity of green fodder thereby decreasing methane production by $5.7 \%$ (Singhal and Madhu Mohini, 2002). Efficiency in ruminant production systems can also be enhanced through the use of concentrate feeds, allowing animals emit less GHG per unit of product (Pelletier et al., 2010). Some methane inhibitors tested in vivo for reduced emission include Bromo-chloromethane (BCM), 2-bromoethenesulfonate (BES), chloroform and cyclodextrin and were found to reduce methane production by up to $50 \%$ in cattle and small ruminants (Knight et al., 2011). Also, reduction in methane emission by 15 to $32 \%$ has been achieved through increasing the level of concentrate in the diet of animals (Singhal and Madhu Mohini, 2002). Diet supplementation has also recorded substantial progress. For instance, molasses urea supplementation reduced $\mathrm{CH}_{4}$ emission by $8.7 \%$ (Srivastava and Garg, 2002) and 21\% from use of monensin; a feed additive and ionophore (De and Singh, 2001; Beauchemin et al., 2008). Improvements in feed efficiency and milk production have been observed by Bell et al. (2011) to significantly reduce GHG emissions and land use of the dairy herd. However, selection for high milk production and decreased productive life, increased death rate, and reduction in fertility are challenges which need to be defeated (Norman et al., 2009). Also, conventional dairy systems have generally lower GHG emission than organic dairy production systems (Heller and Keoleian, 2011; Kristensen et al., 2011). Notably, excretion of nitrogen in most farm animals is dependent on type of diet. Therefore, grouping livestock on the basis of their feed requirements may reduce this source of nitrous oxide in the excreta (Montes et al., 2013). The diet for all animal species should be balanced for amino acids to avoid a depression in feed intake and a decrease in animal productivity. Manufactured amino acids are routinely used to balance the diet 


\section{Adeyemi and Akinfala}

of monogastrics (pigs and poultry), but the environmental impact associated with the manufacturing of these supplements must be considered when including amino acids as a greenhouse gas mitigation strategy. Overall, feeding protein close to the animal's requirement is recommended as an effective mitigation strategy to reduce ammonia and nitrous oxide emissions from manure (Montes et al., 2013).

\section{Livestock management}

Global analyses have clearly shown that greenhouse gas (GHG) emissions particularly of $\mathrm{CH} 4$ and $\mathrm{N}_{2} \mathrm{O}$ are inversely related to animal productivity (Gerber et al., 2011). Increase in animal productivity can be achieved through improvements in animal genetics, feeding, reproduction, health, and overall management of the animal operation. In many parts of the world, reduction in animal numbers was the single most influential mitigation strategy that significantly reduced the $\mathrm{C}$ footprint (Capper et al., 2009). For instance, in The Netherlands, Sheep population has reduced from 57.9 million in 1990 to 45.2 million in 2000, while dairy and beef cattle population have increased slightly (Bannink et al., 2011). The net outcome was a decline in ruminant $\mathrm{CH}_{4}$ emission from 1.45 to 1.31 $\mathrm{Tg} /$ year from 1990 to 2000 (Sejian et al. 2011). Also, practicing proper grazing management system to improve the quality of pastures will increase animal productivity and lower $\mathrm{CH}_{4}$ emission per unit of product. Measurements of $\mathrm{CH}_{4}$ production from grazing beef cows indicated a $25 \%$ reduction in $\mathrm{CH}_{4}$ losses with alfalfa-grass pastures $(7.1 \%$ of gross energy intake) compared to grass-only pastures (9.5\% of gross energy intake) (McCaughey et al., 1999). Early grazing of alfalfa-grass pastures reduced $\mathrm{CH}_{4}$ production by 29 to $45 \%$ gross energy intake in steers compared to grazing at mid and late seasons (Boadi et al., 2004).
Intensive rotational grazing systems are promoted as a good way to increase forage production and reduce nitrous oxide emissions. These systems are characterized by multiple smaller fields called paddocks for the rotation of livestock. Sub-dividing pastures and rotating animals allow farmers manage stocking densities and grazing duration thus, manage nitrogen excreta distribution and vegetation regrowth.

Appropriate management of animal waste products through different mechanisms such as covered storage facilities can reduce the magnitude of methane emission. Separation of manure solids and anaerobic degradation pre-treatment may substantially lower $\mathrm{CH}_{4}$ emission from subsurface manure application, which may otherwise be greater than that from surface applied manure.

Livestock farmers' education, review of product consumption and economic development

Education opportunities for livestock producers especially the Fulani cattle herders in Nigeria may be one component of efforts to promote the use of emissions reducing practices. Such programs could be one avenue for implementing the emissions - reduction initiative. Lowering consumption of meat and milk in areas having high standards of living will support short term response to the GHG mitigation. Therefore, the Intergovernmental Panel on Climate Change (IPCC, 2007) estimated that about $70 \%$ of the global GHG mitigation potential from agriculture lies in developing countries (Smith et al., 2007). Economic development priorities that include the livestock sector are a useful complement to emission reduction efforts. Improved production and resulting incomes from livestock farmers especially, the Fulani cattle herders in Nigeria can both reduce methane emissions per unit of product and improve rural economic conditions. 
Conclusion and recommendation

Livestock production especially ruminants contribute significantly to GHGs emissions. Based on the above points, it appears that there are two possible options that could mitigate methane production by livestock in Nigeria. The first option is at the level of livestock nutrition. The quality of feed given to livestock has a direct relationship with methane production. If the animals are maintained on -polysaccharides i.e. grain, there is the likelihood of by pass of the rumen fermentation. The grains may pass down to the abomasum (true stomach) unchanged thereby escaping the fermentation effects of rumen microbes. Once there is reduced fermentation process due to the by pass activity the chemical and biochemical processes leading to methane production may also likely reduce. The overall effect is that less methane is produced. Nonetheless, the socio-economic implications of feeding grains to cattle, sheep and goats must be considered before this option is adopted. Adding a dash of fish oil to animal fodder had been reported to cut the amount of methane in the belches by nearly half. The overall mitigation approach has to be centered around improving the productivity and efficiency of livestock production. Methane production represents loss of carbon from rumen and therefore an unproductive use of energy. The second option is to give more attention to the production of sheep and goats than cattle as a source of meat. The methane emission factor for sheep and goats is lower ( $5 \mathrm{Kg} / \mathrm{head} /$ year) compared to cattle $(50 \mathrm{Kg} /$ head /year). If more sheep and goats are produced at the expense of cattle, the overall methane per year will definitely reduce. Nonetheless, the socio-economic implications of doing this must also be considered.

\section{References}

Bannink, A., van Schijndel, M. W. and Dijkstra, J. 2011. A model of enteric fermentation in dairy cows to estimate methane emission for the Dutch National Inventory Report using the IPCC Tier 3 approach. Animal Feed Science and Technology, 166-167, 603-618

Basu, A. K. and Bandhyopadhyay, P. K. 2004. The effect of season on the incidence of ticks. Bulletin of Animal Health and Production in Africa, 52(1): 39-42.

Beauchemin, K. A., Kreuzer, M., O'Mara, F. and McAllister, T. A. 2008. Nutritional management for enteric methane abatement: a review. Australian Journal of Experimental Agriculture, 48: 21-27.

Bell, M. J., Wall, E., Russell, G., Simm, G. and Stott, A. W. 2011. The effect of improving cow productivity, fertility, and longevity on the global warming potential of dairy systems. Journal of Dairy Science, 94: 3662-3678.

Bellarby, J., Foereid, B., Hastings, A. and Smith, P. 2008. Cool Farming: Climate impacts of agriculture and mitigation potential

Berman, A. 2005. Estimates of heat stress relief needs for Holstein dairy cows. Journal of Animal Science, 83:1377-1384

Blench, R. 1999. Traditional livestock breeds: geographical distribution and dynamics in relation to the ecology of West Africa Overseas Development Institute, Portland House.

Boadi, D., Benchaar, C., Chiquette, J. and Massé, D. 2004. Mitigation strategies to reduce enteric methane emissions from dairy cows: update review. Canadian Journal of Animal 
Science, 84:319-335.

Boudon, A., Peyraud, J. L., Faverdin, P., Delagarde, R., Delaby, L. and Chaves, A. V. 2009. Effect of rumen fill on intake of fresh perennial ryegrass in young and mature dairy cows grazing or zero-grazing fresh perennial ryegrass. Animal, 3(12):1706-1720

Brooks, D. R. and Hoberg, E. P. 2007. How will global climate change affect parasite-host assemblages? Trends in Parasitology, 23:571-574

Brouwer, E. 1965. Report of subcommittee on constants and factors. In: Proceedings of the $3^{\text {rd }}$ Symposium on Energy Metabolism. Ed: Blaxter, K.L., London: Academic Press. pp. 441-443.

CAIT, 2017. Climate Analysis Indicators Tool. GHG emissions are reported in units of carbon dioxide equivalents. Global Warming Potentials (GWPs) are the 100-year GWPs from the Intergovernmental Panel on Climate Change (IPCC) Second Assessment Report (SAR)

CAIT, 2018. Climate Analysis Indicators Tool. Emissions from other fuel combustion include emissions from stationary and mobile sources such as commercial/institutional, residential, or agricultural/forestry/fishing/fish farms. Other fuel combustion also includes biomass combustion.

Capper, J. L., Cady, R. A. and Bauman, D. E. 2009. The environmental impact of dairy production: 1944 compared with 2007. Journal of Animal Science, 87: 2160-2167.

Chauhan, D. S. and Ghosh, N. 2014. Impact of Climate Change on Livestock Production: A Review. Journal of Animal Research: v.4 n.2, p. 223-239

Chesworth J. 1992. Ruminant Nutrition. The tropical Agriculturalist CTA.
Macmillan.

Dhakal C. K., Regmi P. P., Dhakal I. P, Khanal B. Bhatta U. K, Barsila S. R. and Acharya B. 2013. Perception, Impact and Adaptation to Climate Change: An Analysis of Livestock System in Nepal. J. Anim. Sci. Adv., 3(9): 462-471

Dikshit, A Dhakal C. K., Regmi P. P., Dhakal I. P, Khanal B. Bhatta U. K, Barsila S. R. and Acharya B. K and Birthal, P. S., 2010. FAO., 2009. Grasslands: Enabling their potential to contribute to greenhouse gas mitigation. Submission by the UN Food and Agriculture Organization to the Intergovernmental Panel on Climate Change. FAO, 2009. Wheat Flour. Agribusiness handbook. Investment Centre Division.

EPA. 2010. Environmental Protection Agency. Inventory of U.S. greenhouse gas emissions and sinks: 1990-2008. Washington (DC): U.S. Environmental Protection Agency; 2010 . Available from https://www.epa.gov/sites/productio n/files/201512/documents/508 com plete ghg 1990 2008.pdf

Falkowski, P., Scholes, R. J., Boyle, E., Canadell, J., Canfield, D., Elser, J., Gruber, N., Hibbard, K., Hogberg, P., Linder, S., Mackenzie, F. T., Moore, B., Pedersen, T., Rosenthal, Y., Seitzinger, S., Smetacek, V., and Steffen W. 2000. The global carbon cycle: a test of our knowledge of earth as a system. Science, 290:291-296

FA O S TAT, 2020 . F A O S TAT, Www.fao.org/faostat/en/ Rome: FAO.

FA O S TA T, 2021 . F A O S T A T, Www.fao.org/faostat/en/ Rome: FAO.

FRN， 2014.. Intended Nationally Determined Contribution (INDC).

FRN, 2018. First Biennial Update Report 


\section{Greenhouse gas emissions from livestock and mitigation options in Nigeria}

(BUR1) of the Federal Republic of Nigeria under the United Nations Framework Convention on Climate Change (UNFCCC)

Garnett, T. 2009. Livestock-related greenhouse gas emissions: Impacts and options for policy makers. Environmental Science and Policy, 12, 491-503.

Gerber, P. J., Steinfeld, H. B., Henderson, Mottet, A. C., Opio, J., Dijkman, A. Falcucci, G. and Tempio, G. 2013. Tackling Climate Change Through Livestock: A Global Assessment of Emissions and Mitigation Opportunities FAO, Rome.

Gerber, P., Vellinga, T., Opio, C. and Steinfeld, H. 2011. Productivity gains and greenhouse gas emissions intensity in dairy systems. Livestock Science, 139: 100-108.

Harmon, D. L. and McLeod, K. R. 2001. Glucose uptake and regulation by intestinal tissues: implications and whole-body energetics. Journal of Animal Science, 79 (E. Suppl.): E59E72.

Harmon, D. L., Yamka, R. M. and Elam, N. A. 2004. Factors affecting intestinal starch digestion in ruminants: A review. Canadian Journal of Animal Science, 309-318

Heller, M. C. and Keoleian, G. A. 2011. Life cycle energy and greenhouse gas analysis of a large-scale vertically integrated organic dairy in the United States. Environmental Science and Technology, 45: 1903-1910.

IPCC, 1996. International Panel on Climate Change. Revised 1996 IPCC Guidelines for National Greenhouse Gas Inventories, Reference Manual (Revised).

IPCC, 2006. Guidelines for National Greenhouse Gas Inventories. Agriculture, forestry and other land use; Emission from livestock and manure management, volume 4, Chap. 10, 87pp.

IPCC, 2007. IPCC WGI fourth assessment report. Climatic change: the physical science basis. Intergovernmental Panel on Climate Change, Geneva

Jørgensen, H., Larsen, T., Zhao, Z. Q. and Eggum, B. O. 1997. The energy value of short-chain fatty acids infused into the caecum of pigs. British Journal of Nutrition, 77:745756.

Jørgensen, H., Theil, P. K. and Bach Knudsen, K. E. 2011. Enteric Methane Emission from Pigs. Planet Earth 2011 - Global Warming Challenges and Opportunities for Policy and Practice

Knight, T., Ronimus, R.S., Dey, D., Tootill, C., Naylor, G., Evans, P., Molano, G., Smith, A., Tavendale, M., Pinares-Patino, C. S. and Clark, H. 2011. Chloroform decreases rumen methanogenesis and methanogen populations without altering rumen function in cattle. Animal Feed Science and Technology, 166: 101-112

Kristensen, T., Mogensen, L., Knudsen, M. T. \& Hermansen, J. E. 2011. Effect of production system and farming strategy on greenhouse gas emissions from commercial dairy farms in a life cycle approach. Livestock Science, 140: 136-148.

Kumar, S., Prasad, K. D. and Deb, A. R 2004. Seasonal prevalence of different ecto-parasites infecting cattle and buffaloes. BAU. Journal of Research, 16(1): 159-163

Lawal-Adebowale, O. A. 2012. Dynamics of Ruminant Livestock Management in the Context of the Nigerian A gricul tura 1 S y s t e m . Http://dx.doi.org/10.5772/52923

Llonch, P., Haskell, M. J. Dewhurst, R. J. and Turner, S. P. 2017. Current 
available strategies to mitigate greenhouse gas emissions in livestock systems: an animal welfare perspective. Animal, 11:274-284. Doi:10.1017/S1751731116001440

McAllister, T. A., and Newbold, C. J., 2008 . Redirecting rumen fermentation to reduce methanogenesis. Australian Journal of Experimental Agriculture, 48, $7-13$.

McCaughey, W. P., Wittenberg, K. and Corrigan, D. 1999. Impact of pasture type on methane production by lactating beef cows. Canadian Journal of Animal Science, 79: 221-226.

Montes, F., R. Meinen, C. Dell, A. Rotz, A. N. Hristov, J. Oh, G. Waghorn, P. J. Gerber, B. Henderson, H. P. Makkar, P. 2013. Special topics - mitigation of methane and nitrous oxide emissions from animal operations: II. A review of manure management mitigation options. Journal of Animal Science, 91:50705094. doi:10.2527/jas.2013-6584

Moss A. R. 1994. Methane production by ruminants - Literature review of I. Dietary manipulation to reduce methane production and II. Laboratory procedures for estimating methane potential of diets, Nutr. Abstr. Rev. Ser. B 64:786-806.

Nardone, A. A., Ronchi, B., Lacetera, N., Ranieri, M. S., and Bernabucci, U. 2010. Effects of climate change on animal production and sustainability of livestock systems. Livestock Science, 130: 57-69.

Norman, H. D., Wright, J. R., Hubbard, S. M., Miller, R. H. and Hutchison, J. L. 2009. Reproductive status of Holstein and Jersey cows in the United States. Journal of Dairy Science, 92: 3517-3528

Okediji, F. A. B. 1973. The cattle industry in northern Nigeria. Published by the African Studies Program Indiana University Bloomington, Indiana

Pelletier, N., Pirog, R. and Rasmussen, R. 2010. Agricultural Systems, 103(6):380-389

Pérez-Barbería, F. J. 2017. Scaling methane emissions in ruminants and global estimates in wild populations. Science of Total Environment, 579, $\begin{array}{lllllllll}1 & 5 & 7 & 2 & - & 1 & 5 & 8 & 0\end{array}$. https://doi.org/10.1016/j. scitotenv.2016.11.175

Pérez-Barbería，F. J. 2020. The Ruminant: Life History and Digestive Physiology of a Symbiotic Animal. In: Sustainable and Environmentally Friendly Dairy Farms, S. García-Yuste (Ed.) SpringerBriefs in Applied Sciences a $\mathrm{n} \mathrm{d} \quad \mathrm{T}$ e $\mathrm{ch} \mathrm{n}$ o 1 o g y. https://doi.org/10.1007/978-3-03046060-0 2

Ravagnolo, $\overline{\mathbf{O}}$. and Misztal I. 2000. Genetic Component of Heat Stress in Dairy Cattle, Parameter Estimation. Journal of Dairy Science, 83(9): 2126-2130.

Saggar, S. 2010. Estimation of nitrous oxide emissions from ecosystems and its mitigation technologies. Agriculture, Ecosystem and Environment, 136:189-191. doi:10.1016/j.agee.2010.01.007

Sejian, V., Maurya V. P. and Naqvi, S. M. K. 2011. Effect of thermal, nutritional and combined (thermal and nutritional) stresses on growth and reproductive performance of Malpura ewes under semi-arid tropical environment. Journal of Animal Physiology and Animal Nutrition, 95:252-258.

Sevi, A., Annicchiarico, G., Albenzio, M., Taibi, L., Muscio, A. and Dell'Aquila, S., 2001. Effects of solar radiation and feeding time on 
behavior, immune response and production of lactating ewes under high ambient temperature. Journal of Dairy Science, 84:629-640.

Singhal K. K. and Madhu Mohini 2002. Uncertainty reduction in methane and nitrous oxide gases emission from livestock in India. Project report, Dairy Cattle Nutrition Division, National Dairy Research Institute, Karnal, India, p 62.

Smith, P. Bustamante, M. 2014. Agriculture, Forestry, Forestry and Other Land Use (AFOLU). In Climate Change 2014: Mitigation of Climate Change. Contribution of Working Group III to the Fifth Assessment Report of the Intergovernmental Panel on Climate Change; Cambridge University Press: Cambridge, UK; New York, NY, USA, 2014.

Smith, P. D., Martino, Z., Cai, D., Gwary, H. H., Janzen, P., Kumar, B., McCarl, S., Ogle, F., O'Mara, C., Rice, R. J., Scholes, O., Sirotenko, M., Howden, T., McAllister, G., Pan, V., Romanenkov, S., Rose, U., Schneider, and Towprayoon, S. 2007. Agriculture. In: Chapter 8 of Climate change 2007: Mitigation. Contribution of Working group III to the Fourth Assessment Report of the Intergovernmental Panel on Climate Change. B. Metz, O. R. Davidson, P. R. Bosch, R. Dave, L. A. Meyer, (eds.), Cambridge University Press, Cambridge, UK and New York, USA, pp. 497-540.

Sonaiya, E. B., Branckaert, R. D. and Guèye, E. F. 1999. Research and development options for family poultry. 1st INFPD/FAO Electronic Conference on family poultry, 7 December 1998 - 5 March, 1999.

Thornton, P. K., van de Steeg, J., Notenbaert, A., Herrero, M. 2009.
The impacts of climate change on livestock and livestock systems in developing countries: A review of what we know and what we need to know. Agricultural Systems, 101: 113 -127 .

Tubiello, F. N., Salvatore, M., Cóndor Golec, R. D., Ferrara, A., Rossi, S., Biancalani, R., Federici, S., Jacobs, H., Flammini, A. 2014. Agriculture, Forestry and Other Land Use Emissions by Sources and Removals by Sinks: 1990 - 2011 Analysis. Food and Agriculture Organisation of the United Nation, D O I : 10.13140/2.1.4143.4245

UN, 2017. United Nations, Department of Economic and Social Affairs, Population Division 2017. World population prospects: the 2017 revision, Key findings and advance tables. Working Paper No. $\mathrm{ESA} / \mathrm{P} / \mathrm{WP} / 248$. Available from https://esa.un.org/unpd/wpp/publicat ions/files/wpp2017 keyfindings.pdf

Upadhaya, R. C., Singh S. V., Kumar, A., Gupta, S. K. and Ashutosh. 2007. Impact of climate change on Milk production of Murrah buffaloes. Italian Journal of Animal Science, 6 (Suppl.2): 1329-1332

USAID 2019. United States Agency for International Development: Greenhouse Gas Emissions in Nigeria

Vibart, R., de Klein, C., Jonker, A., van der Weerden, T., Bannink, A., Crompton, L., Durand, A., Eugène, M., Klumpp, K., Kuhla, B., Lanigan, G., Ramin, M., and Salazar, F. 2021. Challenges and opportunities to capture dietary effects in on-farm greenhouse gas emissions models of ruminant systems. Science of the Total Environment, 769 (2021) 144989

Williams, Y. J., Doyle, P. T., and Egan, A. 


\section{Adeyemi and Akinfala}

R. 2014. Diurnal variation in rumen fill of dairy cows grazing Persian clover at different pasture allowances. Animal Production Science, 59(9):1388-1393

Received: $20^{\text {th }}$ May, 2021

Accepted: $15^{\text {th }}$ August, 2021 